Article

\title{
Evaluation of a New Urban Cycling Infrastructure in Caceres (Spain)
}

\author{
Pedro Plasencia-Lozano
}

check for updates

Citation: Plasencia-Lozano, $\mathrm{P}$. Evaluation of a New Urban Cycling Infrastructure in Caceres (Spain). Sustainability 2021, 13, 1910. https://doi.org/10.3390/su13041910

Academic Editors:

Alexandros Nikitas and Efthimios Bakogiannis

Received: 13 January 2021

Accepted: 4 February 2021

Published: 10 February 2021

Publisher's Note: MDPI stays neutral with regard to jurisdictional claims in published maps and institutional affiliations.

Copyright: (C) 2021 by the author. Licensee MDPI, Basel, Switzerland. This article is an open access article distributed under the terms and conditions of the Creative Commons Attribution (CC BY) license (https:/ / creativecommons.org/licenses/by/ $4.0 /)$.
Department of Construction and Manufacturing Engineering, University of Oviedo, 33600 Mieres, Spain; plasenciapedro@uniovi.es

\begin{abstract}
The purpose of the research is the evaluation of the impact of a new bike lane network built in Cáceres (Spain) in October 2019, a city with a weak tradition in the use of bicycles. Prior to the new project, the percentage of displacement by bicycle was under $0.2 \%$ (by contrast, private cars was 56\%). The project has introduced a real network in 33 new streets and avenues, and 250 new parking places for bicycles. The impact has been evaluated by two online surveys, one conducted in November-December 2019 just after the inauguration, and the other conducted in January-February 2020. For that, the impact evolution after the first 3 months has also been evaluated. The result allows to analyze the citizens' response to the new infrastructure; the main conclusion is that the effect of the built infrastructure is clearly positive in terms of new users, new potential users, and bike general image for the citizens. Moreover, this positive effect has grown after the first 3 months.
\end{abstract}

Keywords: bicycle network; surveys; new infrastructure; planning; mid-size city

\section{Introduction}

Urban cycling has been gaining significant political and public support in Spanish cities in recent years. Policies and new projects have been introduced to increase the number of bike lanes, in order to change the traditional urban mobility paradigm, which has been car-centric for decades.

The situation was very different a few years ago. Even though the advantages of using the bicycle as a means of urban transport are well known in the subjects of environment or improving health, to mention only a few [1-3], Spain has traditionally shown strong resistance to accepting the bike as an urban vehicle. For instance, the Special Eurobarometer on Attitudes of Europeans towards urban mobility [4] questioned "How often do you cycle?": Spain was in the last position (only ahead Cyprus and Malta), with only $4 \%$ the citizens using a bicycle everyday (far from $43 \%$ of Netherland, and from $12 \%$ of the EU28), and $73 \%$ the citizens who did not use anytime (50\% in the whole EU28). Moreover, in the Special Eurobarometer on Quality of Transport [5], to the question "On a typical day, which mode of transport do you use most often?", bicycle was the answer chosen by $8 \%$ of the EU28 citizens, while in Spain this figure was 3\%, far from Netherlands (36\%), Denmark $(23 \%)$ or Hungary $(22 \%)$.

However, the reports from the Observatory of urban mobility [6] show a significant increase of bicycle facilities built in Spanish cities (Table 1): Seville was the first big city in working on these policies, after the 2007 municipal Bicycle Plan for Seville [7]; while bicycle facilities in Madrid, Barcelona, and Alicante have risen since 2012. The cases of Malaga, Granada, and Tarragona prove that some other cities are still reticent about constructing a cycling infrastructure in their streets.

One of the most important questions is the impact these new infrastructures have on generating new users. Several studies [8,9] have shown a clear correlation between the number of cycling facilities provided and the percentage of people that use the bicycle for commuting. It has been reported that "if bicycling is to be a viable mode of transportation, it must have appropriate facilities" [10]. 
Table 1. Bicycle lanes length in metropolitan capitals $(\mathrm{km})$, and density ( $\mathrm{km}$ bicycle lanes/million inhabitants). The expression "bicycle lane" covers all types of lanes conceived for bikes, including shared roadways.

\begin{tabular}{|c|c|c|c|c|c|c|c|}
\hline & 2008 & 2010 & 2012 & 2014 & 2016 & 2018 & $\%$ Increase \\
\hline \multicolumn{8}{|l|}{ Madrid } \\
\hline Length $(\mathrm{km})$ & 151 & 151 & 290 & 447 & 590 & 601 & $298 \%$ \\
\hline $\begin{array}{c}\text { Density (km bicycle } \\
\text { lanes/million inhabitants) }\end{array}$ & 47 & 46 & 90 & 88 & 186 & 186 & $296 \%$ \\
\hline \multicolumn{8}{|l|}{ Barcelona } \\
\hline Length $(\mathrm{km})$ & 140 & 159 & 187 & 558 & 1167 & 1468 & $949 \%$ \\
\hline $\begin{array}{c}\text { Density (km bicycle } \\
\text { lanes/million inhabitants) }\end{array}$ & 87 & 98 & 115 & - & 725 & 906 & $941 \%$ \\
\hline \multicolumn{8}{|l|}{ Valencia } \\
\hline Length $(\mathrm{km})$ & 80 & 139 & 137 & 168 & 168 & 175 & $119 \%$ \\
\hline $\begin{array}{c}\text { Density (km bicycle } \\
\text { lanes/million inhabitants) }\end{array}$ & 99 & 171 & 172 & 174 & 212 & 220 & $122 \%$ \\
\hline \multicolumn{8}{|l|}{ Sevilla } \\
\hline Length $(\mathrm{km})$ & 147 & 147 & 136 & 136 & 166 & 166 & $13 \%$ \\
\hline $\begin{array}{c}\text { Density (km bicycle } \\
\text { lanes/million inhabitants) }\end{array}$ & 210 & 209 & 194 & 195 & 240 & 241 & $15 \%$ \\
\hline \multicolumn{8}{|l|}{ Málaga } \\
\hline Length $(\mathrm{km})$ & 25 & 30 & 35 & - & 35 & 44 & $76 \%$ \\
\hline $\begin{array}{c}\text { Density (km bicycle } \\
\text { lanes/million inhabitants) }\end{array}$ & 44 & 53 & 62 & - & 62 & 77 & $75 \%$ \\
\hline \multicolumn{8}{|l|}{ Granada } \\
\hline Length $(\mathrm{km})$ & 9 & 9 & 9 & 27 & 27 & 27 & $200 \%$ \\
\hline $\begin{array}{c}\text { Density (km bicycle } \\
\text { lanes/million inhabitants }\end{array}$ & 38 & 38 & 38 & 116 & 115 & 117 & $208 \%$ \\
\hline \multicolumn{8}{|l|}{ Alicante } \\
\hline Length $(\mathrm{km})$ & 23 & 41 & 111 & 155 & 155 & 174 & $657 \%$ \\
\hline $\begin{array}{c}\text { Density }(\mathrm{km} \text { bicycle } \\
\text { lanes /million inhabitants }\end{array}$ & 69 & 122 & 332 & - & 469 & 522 & $657 \%$ \\
\hline \multicolumn{8}{|l|}{ Tarragona } \\
\hline Length $(\mathrm{km})$ & - & 6 & 10 & 11 & 13 & 14 & $133 \%$ \\
\hline $\begin{array}{c}\text { Density (km bicycle } \\
\text { lanes/million inhabitants }\end{array}$ & - & 42 & 75 & 76 & 91 & 99 & $136 \%$ \\
\hline
\end{tabular}

Source: Observatory of urban mobility [6].

Some studies have also demonstrated the reluctance of countries with less cycling culture to accept new bike infrastructures than countries with a longer cycling tradition [11,12], and the need for local authorities to create a cycling-friendly culture to encourage its use by citizens [13].

Another idea merges from other studies: the importance of safety over other parameters like time travel or surface quality for cyclist $[14,15]$. Safety has been directly linked to good facilities [16,17], and also to respect from other users: car drivers. Some studies have detected problems due to drivers who don't know how to drive safely near bicycles $[18,19]$. It is clear that if motorists or car drivers do not have previous experience with bikers, the respect to bikers will only emerge after some time sharing the streets.

This implies that most of potential users will not ride their bike until a bicycle infrastructure has been built and until drivers have become aware that there is a new user in the streets who must be respected. It is also known that those who usually ride bicycles feel safer than new users [20], so the lack of safety is a dissuading factor for the use of bicycles in cities without a cycling tradition.

Therefore, during a time, cyclists will make little use of the new bicycle infrastructure, which will be very underused during the first months. This reality could even dissuade 
government administrations from making such investments, which may at first not be well understood by the traditionally car-centered citizenship.

Thus, it would be of interest to know the evolution of acceptance of a new infrastructure during the first months after it has been put into service in a city with no previous cycling culture, which is the case of most Spanish cities. Some before-after studies have been developed concerning the implementation of bike sharing schemes [21-23], and an excellent review was recently made by Mölenberg et al. [24], with an evaluation of 31 studies extracted from 125 full-text articles; although there are a wide range of experiences analyzed, none of them cover the evolution of the acceptance during the first 6 months and/or examines the case of a whole new cycling network in the city with no previous cycling culture. As an example, Vasilev et al. [25] launched a survey for a research on a new infrastructure around a year after the changes took place, and Goodman et al. [26] evaluated the impacts after the first and the second year of commissioning; moreover, a huge number of studies evaluated the impact of singular new infrastructures (a new bridge for bicycles and pedestrians [27], a street intervention [28], a new cycleway [25,29]), but to our knowledge, the case of a whole new infrastructure is yet to be researched. Hence, this study pretends to cover this gap.

Hence, the aim of the research is to evaluate the early impact of the construction of the very first cycling infrastructure network in an underdeveloped city in terms of bicycle infrastructures. Cáceres, a Spanish city which previously had hardly anything conceived for bicycles, in which a new bicycle infrastructure was constructed in 2019, has therefore been taken as the study case. At the end of construction, a first public survey was taken to find out its impact, and 6 months later a second one.

\section{Materials and Methods}

The method of study was to take two surveys after the new infrastructure was put into use. The first survey was taken 2 months after construction, and the second, 3 months from the first (Figure 1). This was intended to find out the impact of construction of the new cyclist infrastructure in Cáceres and also the extent of its acceptance a few months after opening. Data collected with surveys provide essential information for traffic planners, public transport providers, infrastructure authorities, and transportation scientists; the survey methodology is used for studies on bicycles in many cases [30-32].

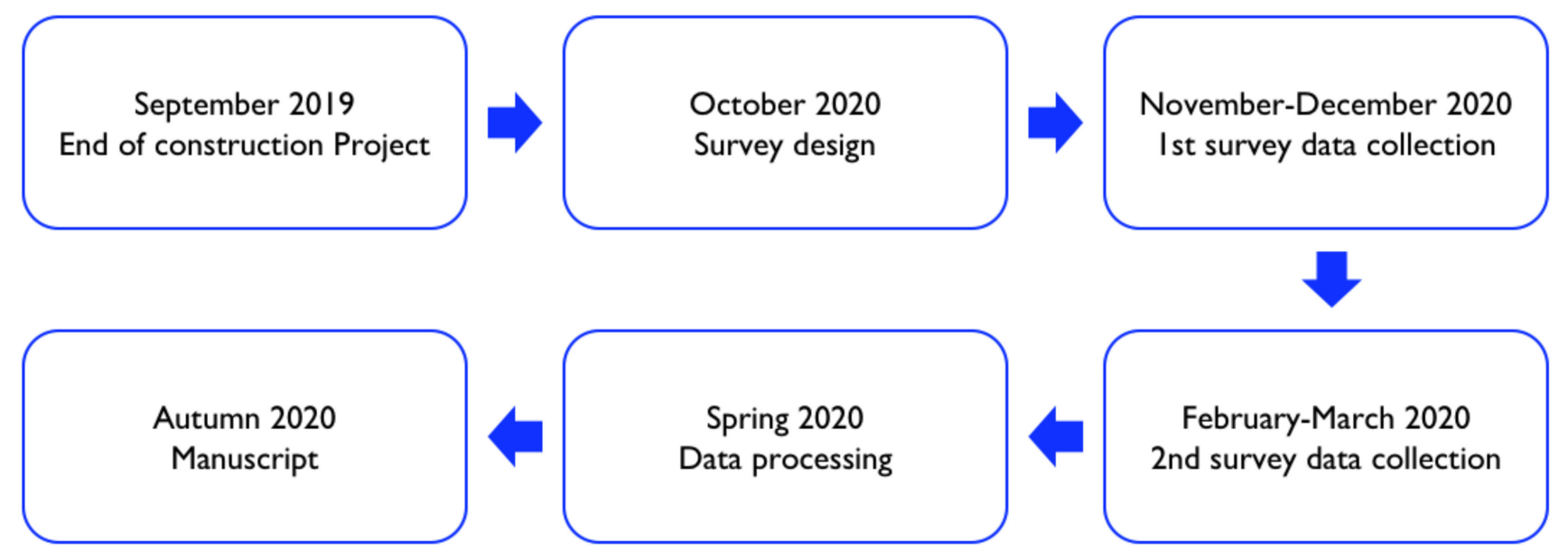

Figure 1. Data flow diagram, describing the timing and the methodological steps.

\subsection{Description of the Case Study}

Cáceres is a small provincial capital in Spain with no cycling tradition. It has a classic European urban structure, with a walled historic city center, originally Roman and Moorish, today a World Heritage site, and entirely zoned for pedestrians only. City development 
mostly began in the 20th century, and today has a wide area of expansion with successive enlargements, a series of peripheral neighborhoods that have grown up following the suburban model, and some single-family housing developments on the outskirts [33]. In general, it is a compact city with streets and avenues, with well-defined parks, and sidewalks that are not very wide with some exceptions ( $4.2 \mathrm{~m}$ wide in the remodeled $\mathrm{Av}$. Virgen de Guadalupe). According to 2019 data, the city population is 96,720 [34].

In Cáceres, the summers are short, hot, dry, and mostly clear, and the winters are cold and partly cloudy. Over the course of the year, the temperature typically varies from $1{ }^{\circ} \mathrm{C}$ to $34^{\circ} \mathrm{C}$ and is rarely below $-4{ }^{\circ} \mathrm{C}$ or above $38^{\circ} \mathrm{C}$. The wetter season lasts 8.2 months, from 19 September to 26 May, with a greater than $14 \%$ chance of a given day being a wet day. The chance of a wet day peaks at $26 \%$ on 30 October. The drier season lasts 3.8 months, from 26 May to 19 September. The smallest chance of a wet day is $1 \%$ on $30 \mathrm{July}$. Wet days are differentiated between those with rain alone, snow alone, or a mixture of the two. Based on this categorization, the most common form of precipitation throughout the year is rain alone, with a peak probability of $26 \%$ on 30 October [35].

In 2004, a bicycle lane was built in the outskirts along a bypass, and some streets with parking spots for bikes were usually empty. However, less than $0.14 \%$ of daily travel was by bicycle in 2014 according to the PIMUS Urban Mobility Plan PIMUS [36], despite its Mediterranean climate and its relatively good orography in the expanded part of the city and in the south (somewhat more complicated than in the north). The PIMUS states that "there is no reason for the scant use of bicycles", also emphasizing the scant effect of parameters such as the urban structure, gender or the demographic pyramid on people's willingness to use bikes.

In 2019, from July to September, a project drafted the year before, which introduced a connected enmeshed bicycle network along with other elements for cyclists, was constructed in the city (Figure 2). The budget was $143,250 €$, and the main facilities were (Figure 3):

- $\quad$ Bike passes in the main junctions

- Segregated bike lanes in some roundabouts

- Desire lanes making it possible to go between streets that are close to each other, but poorly connected

- Introduction of slow streets: shared roadway with speed limited to $20 \mathrm{~km} / \mathrm{h}$, and with a bike-friendly road bump each $300 \mathrm{~m}$

- New bicycle lanes in some points

- Installation of 250 bicycle parking points

- Shared roadway net open to both bicycle and motor vehicle travel $(30 \mathrm{~km} / \mathrm{hr}$. speed limit and bicycle signs)

Although the project was modified (it included also a segregated cycle light signal in some traffic lights, for instance), the constructed facilities conserved the main objectives of the original proposal.

\subsection{Procedure}

A survey was designed as an online questionnaire; this modality has been proved to be as good as telephone or direct surveys $[37,38]$ and is regularly employed by scholars and planners [39-41]. The target group included people who lives in Cáceres or regularly visit the city, as many people do not live there each working day. Questions are reflected in Table 2.

The first survey was conducted between 11 November and 13 December 2019. Respondents were invited to participate using different tools: Facebook groups, Twitter, and also posters; moreover, different email invitations were sent to most of the associations listed in the municipality web page. The second survey was conducted between 16 February and 25 March 2020; the questionnaire's link was disseminated through the same channels, with the clear warning of being the second part of a previous survey. For that, respondent of the first survey could answer the second one, too. 


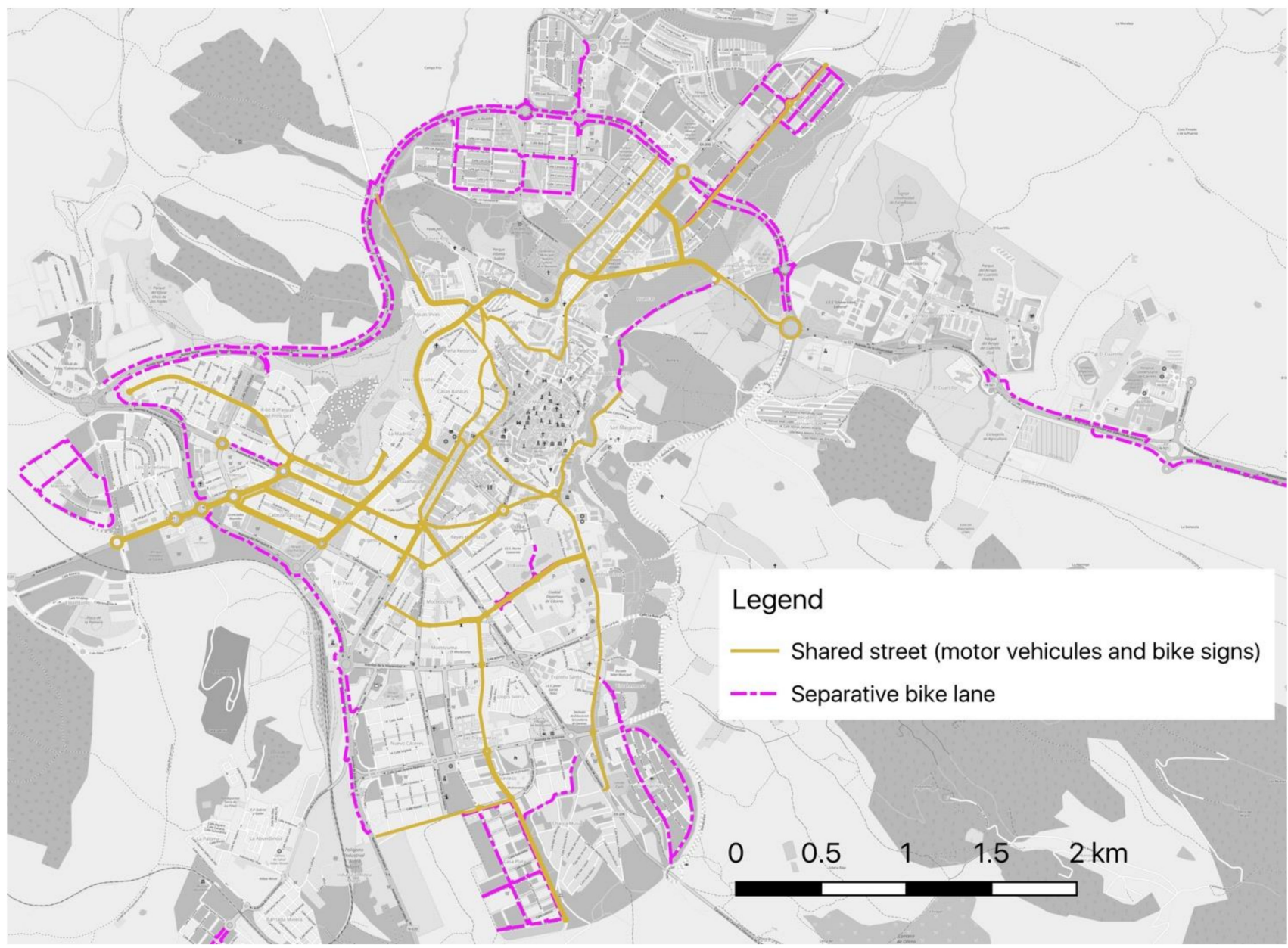

Figure 2. Current bike lane network in Cáceres. All the shared streets and some new segregated bike lanes are part of the new project. Source: developed by the authors, QGIS and OpenStreetMap were used for the geographical background design.

\subsection{Sampling}

From the first survey, a total of 407 responses were obtained, 196 being the number of responses obtained from the second wave (Table 3). Respondents who did not answer the second question or under 16 years old were removed, as they are not allowed to ride a bicycle without supervision; those who did not answer the third question were also removed from the sample, as the most relevant background characteristic was not. As a result of the above criteria, 374 valid responses remained in the first survey, and 167 in the second one. The people surveyed were aged 16-70 in the first round and 19-71 in the second survey.

The margin of error can be calculated according to the following formula:

$$
n=\frac{N \cdot z_{\frac{\alpha}{2}}^{2} \cdot p \cdot(1-p)}{e^{2} \cdot(N-1)+z_{\frac{\alpha}{2}}^{2} \cdot p \cdot(1-p)}
$$

The values to be set are population size $N=81,507$ (people over 15 years old living in Cáceres); sample sizes $n=374$ and $n=167$, with $p=0.5$. Considering the normal distribution, value $z_{\frac{\alpha}{2}}=1.96$ is set for a confidence level $(1-\alpha)=95 \%$. Therewith, the margin of error is $e \stackrel{2}{=} \pm 5.06 \%$ for the first survey and $e= \pm 7.58 \%$ for the second one. 


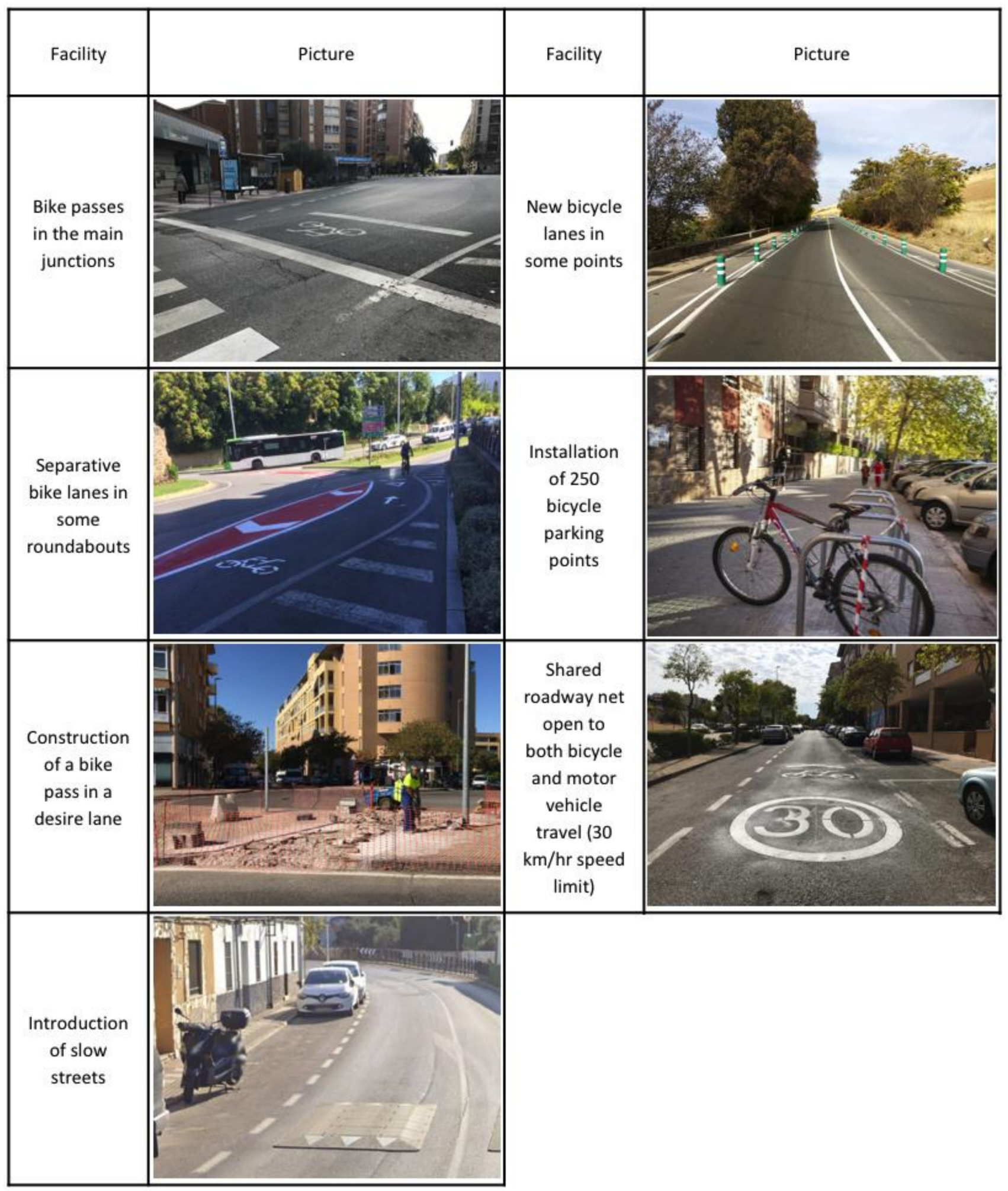

Figure 3. Facilities built in Cáceres (photographs by David Asunción). 
Table 2. Questions and answers.

\begin{tabular}{|c|c|}
\hline Questions & Possible Answers \\
\hline Gender & Women; Men \\
\hline Age & Open \\
\hline You live in the city... & $\begin{array}{l}\text { Every day; Working days; Weekends; Some weekends, to visit } \\
\text { family and Friends; Some working days each month }\end{array}$ \\
\hline $\begin{array}{l}\text { Have you ridden a bicycle for some new reason in recent weeks } \\
\text { due to the new bicycle facilities? }\end{array}$ & Yes; No \\
\hline $\begin{array}{l}\text { If you have to choose between these new bike infrastructures, } \\
\text { which one has been the most positive? }\end{array}$ & $\begin{array}{l}\text { Segregated bike lanes in some roundabouts; New shared } \\
\text { roadway net open to both bicycle and motor vehicle travel; } \\
\text { Installation of new bicycle parking points; New segregated bike } \\
\text { lane in Ronda Vadillo; Bike passes in the main junctions; None } \\
\text { of them }\end{array}$ \\
\hline $\begin{array}{l}\text { Do you think that new bicycle facilities projects promote travel } \\
\text { by bicycle? }\end{array}$ & Yes; No; Maybe \\
\hline $\begin{array}{l}\text { You think that investing in bicycle infrastructure in Cáceres is: } \\
\text { (you can answer simultaneously up to three possible options) }\end{array}$ & $\begin{array}{l}\text { Recommended; Important; Necessary; Positive; Innovator; } \\
\text { Absurd; Excessive; Unnecessary; Premature }\end{array}$ \\
\hline $\begin{array}{l}\text { In Cáceres, in your opinion, what further steps should be taken } \\
\text { by government administration, concerning bike or VMP } \\
\text { mobility? (you can answer simultaneously several choices) }\end{array}$ & $\begin{array}{l}\text { It is enough; Increase the number of bike passes at stoplights; } \\
\text { Increase segregated bike lanes, even reducing parking slots or } \\
\text { car lanes; Increase bicycle parking points; Increase shared lanes } \\
\text { open to both bicycle and motor vehicles; Implement an electric } \\
\text { bicycle rental service; Eliminate one of the parking lanes in Av. } \\
\text { España and include a segregated bike path; Allow bicycles on } \\
\text { urban buses; Subsidize the purchase of electric bicycles and } \\
\text { electric scooters; Other ... }\end{array}$ \\
\hline $\begin{array}{l}\text { In your opinion, has the new bicycle infrastructure increased } \\
\text { traffic safety for bikes in Cáceres? }\end{array}$ & $\begin{array}{l}\text { Quite, the difference is appreciable; A lot, it has changed } \\
\text { noticeably; Nothing; A little, although much remains to be done. }\end{array}$ \\
\hline
\end{tabular}

Source: the authors.

Table 3. Respondents by gender and age, and comparison to real population in Cáceres.

\begin{tabular}{lcccccc}
\hline \multirow{2}{*}{ Category } & \multicolumn{2}{c}{ Sample 1st Survey } & \multicolumn{2}{c}{ Sample 2nd Survey } & Cáceres \\
\cline { 3 - 7 } & & Frequency & Percentage & Frequency & Percentage & \\
\hline \multirow{2}{*}{ Gender } & Female & 164 & $43.8 \%$ & 70 & $42 \%$ & $51.9 \%$ \\
& Male & 210 & $56.2 \%$ & 97 & $58 \%$ & $48.1 \%$ \\
\hline \multirow{4}{*}{ Age } & $16-29$ & 80 & $22.6 \%$ & 30 & $18.0 \%$ & $16.8 \%$ \\
& $30-49$ & 193 & $54.7 \%$ & 90 & $53.9 \%$ & $35.1 \%$ \\
& $50-64$ & 74 & $21.0 \%$ & 38 & $22.7 \%$ & $26.9 \%$ \\
& $>65$ & 6 & $1.7 \%$ & 9 & $5.4 \%$ & $21.2 \%$ \\
\hline
\end{tabular}

Source: the authors.

The samples in both surveys, in terms of gender and age, were similar. However, there were notable differences with respect to reality. Women are underrepresented in both samples. Furthermore, people over 65 years are hardly represented at all, while there is a significant overrepresentation of people aged 30-49.

\section{Results}

Question 4 asked whether the respondents had ridden a bicycle for some new reason in recent weeks. The affirmative answers in the first survey were $12.8 \%$ of the total; in the second survey, this percentage rose by $4.5 \%$. This increase was by both men and women, although somewhat more men (Table 4). 
Table 4. Question 4. Have you ridden a bicycle for some new reason in recent weeks due to the new bicycle facilities? (by gender).

\begin{tabular}{|c|c|c|c|c|c|c|c|c|c|c|c|c|c|}
\hline \multirow[b]{3}{*}{ Yes } & \multicolumn{6}{|c|}{ 1st Survey } & \multicolumn{6}{|c|}{ 2nd Survey } & \multirow{3}{*}{$\begin{array}{c}\text { Difference } \\
4.5 \%\end{array}$} \\
\hline & \multicolumn{2}{|c|}{ Women } & \multicolumn{2}{|c|}{ Men } & \multicolumn{2}{|c|}{ Total } & \multicolumn{2}{|c|}{ Women } & \multicolumn{2}{|c|}{ Men } & \multicolumn{2}{|c|}{ Total } & \\
\hline & 14 & $8.5 \%$ & 34 & $16.2 \%$ & 48 & $12.8 \%$ & 8 & $11.4 \%$ & 21 & $21.7 \%$ & 29 & $17.4 \%$ & \\
\hline No & 150 & $91.5 \%$ & 176 & $83.8 \%$ & 326 & $87.2 \%$ & 62 & $88.6 \%$ & 75 & $77.3 \%$ & 137 & $82.0 \%$ & $-5.1 \%$ \\
\hline Blank & 0 & $0.0 \%$ & 0 & $0.0 \%$ & 0 & $0.0 \%$ & 0 & $0.0 \%$ & 1 & $1.0 \%$ & 1 & $0.6 \%$ & $0.6 \%$ \\
\hline Total & 164 & $100.0 \%$ & 210 & $100.0 \%$ & 374 & $100.0 \%$ & 70 & $100.0 \%$ & 97 & $100.0 \%$ & 167 & $100.0 \%$ & $0.0 \%$ \\
\hline
\end{tabular}

On the age, the affirmative answers grew up in almost all the groups between the first and second surveys. The biggest increase was detected in the 16-29 years old group; in contrast, people over 65 increased the negative answer (Table 5).

Table 5. Question 4. Have you ridden a bicycle for some new reason in recent weeks due to the new bicycle facilities? (by age).

\begin{tabular}{|c|c|c|c|c|c|c|c|c|c|c|c|c|c|c|c|c|}
\hline \multirow[b]{3}{*}{ Yes } & \multicolumn{8}{|c|}{ 1st Survey } & \multicolumn{8}{|c|}{ 2nd Survey } \\
\hline & \multicolumn{2}{|c|}{$16-29$} & \multicolumn{2}{|c|}{$30-49$} & \multicolumn{2}{|c|}{$50-64$} & \multicolumn{2}{|c|}{$>65$} & \multicolumn{2}{|c|}{$16-29$} & \multicolumn{2}{|c|}{$30-49$} & \multicolumn{2}{|c|}{$50-64$} & \multicolumn{2}{|c|}{$>65$} \\
\hline & 7 & $8.8 \%$ & 27 & $14.0 \%$ & 10 & $13.5 \%$ & 1 & $16.7 \%$ & 7 & $23.3 \%$ & 18 & $20.0 \%$ & 4 & $10.5 \%$ & 0 & $0.0 \%$ \\
\hline No & 73 & $91.2 \%$ & 166 & $86.0 \%$ & 64 & $86.5 \%$ & 5 & $83.3 \%$ & 23 & $76.7 \%$ & 72 & $80.0 \%$ & 33 & $86.9 \%$ & 9 & $100.0 \%$ \\
\hline Blank & 0 & $0.0 \%$ & 0 & $0.0 \%$ & 0 & $0.0 \%$ & 0 & $0.0 \%$ & 0 & $0.0 \%$ & 0 & $0.0 \%$ & 1 & $2.6 \%$ & 0 & $0.0 \%$ \\
\hline Total & 80 & $100.0 \%$ & 193 & $100.0 \%$ & 74 & $100.0 \%$ & 6 & $100.0 \%$ & 30 & $100.0 \%$ & 90 & $100.0 \%$ & 38 & $100.0 \%$ & 9 & $100.0 \%$ \\
\hline
\end{tabular}

Source: the authors.

In Question 5, there is a choice of several possible answers about the types of infrastructures created. A first analysis was based on rejection of the facilities constructed: In this case, the choice "none of them" must be studied with particular interest. A small decrease may be observed in the group of persons who chose this answer: $23.0 \%$ in the first round and $22.7 \%$ in the second (Table 6). The same analysis done by age shows that the option "none of them" increased in the 16-29 and 50-64 age groups and fell in the 30-49 and over 65 age groups (Table 7 ).

Table 6. Question 5. If you have to choose between these new bike infrastructures, which one has been the most positive? (by gender).

\begin{tabular}{|c|c|c|c|c|c|c|c|c|c|c|c|c|c|}
\hline \multirow[b]{3}{*}{$\begin{array}{l}\text { Segregated bike lanes in } \\
\text { some roundabouts }\end{array}$} & \multicolumn{6}{|c|}{ 1st Survey } & \multicolumn{6}{|c|}{ 2nd Survey } & \multirow{3}{*}{$\begin{array}{c}\text { Difference } \\
4.4 \%\end{array}$} \\
\hline & \multicolumn{2}{|c|}{ Women } & \multicolumn{2}{|c|}{ Men } & \multicolumn{2}{|c|}{ Total } & \multicolumn{2}{|c|}{ Women } & \multicolumn{2}{|c|}{ Men } & \multicolumn{2}{|c|}{ Total } & \\
\hline & 12 & $7.3 \%$ & 12 & $5.7 \%$ & 24 & $6.4 \%$ & 8 & $11.4 \%$ & 10 & $10.3 \%$ & 18 & $10.8 \%$ & \\
\hline $\begin{array}{l}\text { New shared roadway } \\
\text { net open to both bicycle } \\
\text { and motor vehicle travel }\end{array}$ & 28 & $17.1 \%$ & 28 & $13.3 \%$ & 56 & $15.0 \%$ & 11 & $15.7 \%$ & 28 & $28.9 \%$ & 39 & $23.3 \%$ & $8.3 \%$ \\
\hline $\begin{array}{l}\text { Installation of new } \\
\text { bicycle parking points }\end{array}$ & 40 & $24.4 \%$ & 40 & $19.1 \%$ & 80 & $21.4 \%$ & 12 & $17.1 \%$ & 20 & $20.6 \%$ & 32 & $19.2 \%$ & $-2.2 \%$ \\
\hline $\begin{array}{l}\text { New segregated bike } \\
\text { lane in Ronda Vadillo }\end{array}$ & 16 & $9.8 \%$ & 16 & $7.6 \%$ & 32 & $8.6 \%$ & 14 & $20.0 \%$ & 13 & $13.4 \%$ & 27 & $16.2 \%$ & $7.6 \%$ \\
\hline $\begin{array}{l}\text { Bike passes in the } \\
\text { main junctions }\end{array}$ & 12 & $7.3 \%$ & 12 & $5.7 \%$ & 24 & $6.4 \%$ & 2 & $2.9 \%$ & 5 & $5.1 \%$ & 7 & $4.2 \%$ & $-2.2 \%$ \\
\hline None of them & 43 & $26.2 \%$ & 43 & $20.5 \%$ & 86 & $23.0 \%$ & 19 & $27.1 \%$ & 19 & $19.6 \%$ & 38 & $22.7 \%$ & $-0.3 \%$ \\
\hline Blank & 5 & $3.0 \%$ & 1 & $0.5 \%$ & 6 & $1.6 \%$ & 2 & $2.9 \%$ & 0 & $0.0 \%$ & 2 & $1.2 \%$ & $-0.4 \%$ \\
\hline Other & 8 & $4.9 \%$ & 58 & $27.6 \%$ & 66 & $17.6 \%$ & 2 & $2.9 \%$ & 2 & $2.1 \%$ & 4 & $2.4 \%$ & $-15.2 \%$ \\
\hline
\end{tabular}


Table 7. Question 5. If you have to choose between these new bike infrastructures, which one has been the most positive? (by age).

\begin{tabular}{|c|c|c|c|c|c|c|c|c|c|c|c|c|c|c|c|c|}
\hline \multirow[b]{3}{*}{$\begin{array}{l}\text { Segregated bike lanes in } \\
\text { some roundabouts }\end{array}$} & \multicolumn{8}{|c|}{ 1st Survey } & \multicolumn{8}{|c|}{ 2nd Survey } \\
\hline & \multicolumn{2}{|c|}{$16-29$} & \multicolumn{2}{|c|}{$30-49$} & \multicolumn{2}{|c|}{$50-64$} & \multicolumn{2}{|c|}{$>65$} & \multicolumn{2}{|c|}{$16-29$} & \multicolumn{2}{|c|}{$30-49$} & \multicolumn{2}{|c|}{$50-64$} & \multicolumn{2}{|c|}{$>65$} \\
\hline & 8 & $10.0 \%$ & 7 & $3.6 \%$ & 7 & $9.4 \%$ & 0 & $0.0 \%$ & 4 & $13.2 \%$ & 8 & $8.9 \%$ & 3 & $7.9 \%$ & 3 & $33.4 \%$ \\
\hline $\begin{array}{l}\text { New shared roadway net } \\
\text { open to both bicycle and } \\
\text { motor vehicle travel }\end{array}$ & 12 & $15.0 \%$ & 45 & $23.3 \%$ & 17 & $23.0 \%$ & 1 & $16.7 \%$ & 6 & $20.0 \%$ & 24 & $26.7 \%$ & 7 & $18.4 \%$ & 2 & $22.2 \%$ \\
\hline $\begin{array}{l}\text { Installation of new bicycle } \\
\text { parking points }\end{array}$ & 21 & $26.3 \%$ & 32 & $16.6 \%$ & 11 & $14.8 \%$ & 1 & $16.7 \%$ & 8 & $26.7 \%$ & 20 & $22.2 \%$ & 2 & $5.2 \%$ & 2 & $22.2 \%$ \\
\hline $\begin{array}{c}\text { New segregated bike lane } \\
\text { in Ronda Vadillo }\end{array}$ & 10 & $12.5 \%$ & 23 & $11.9 \%$ & 12 & $16.2 \%$ & 1 & $16.7 \%$ & 2 & $6.7 \%$ & 14 & $15.6 \%$ & 10 & $26.3 \%$ & 1 & $11.1 \%$ \\
\hline $\begin{array}{l}\text { Bike passes in the main } \\
\text { junctions }\end{array}$ & 7 & $8.8 \%$ & 15 & $7.8 \%$ & 5 & $6.8 \%$ & 0 & $0.0 \%$ & 2 & $6.7 \%$ & 3 & $3.3 \%$ & 2 & $5.3 \%$ & 0 & $0.0 \%$ \\
\hline None of them & 17 & $21.3 \%$ & 53 & $27.5 \%$ & 15 & $20.3 \%$ & 2 & $33.3 \%$ & 8 & $26.7 \%$ & 17 & $18.9 \%$ & 12 & $31.6 \%$ & 1 & $11.1 \%$ \\
\hline Blank & 1 & $1.3 \%$ & 2 & $1.0 \%$ & 2 & $2.7 \%$ & 1 & $16.7 \%$ & 0 & $0.0 \%$ & 2 & $2.2 \%$ & 0 & $0.0 \%$ & 0 & $0.0 \%$ \\
\hline Other & 4 & $5.0 \%$ & 16 & $8.3 \%$ & 5 & $6.8 \%$ & 0 & $0.0 \%$ & 0 & $0.0 \%$ & 2 & $2.2 \%$ & 2 & $5.3 \%$ & 0 & $0.0 \%$ \\
\hline
\end{tabular}

Source: the authors.

In addition, there is a certain uniformity insofar as acceptance of bike passes in the main junctions: The percentage of people who select it as the most positive decreases from the first to the second survey in all the age groups and in both genders.

However, a second analysis was based on acceptance of the new facilities. In this case, the option "other" would be understood as another rejection, since such persons were not satisfied with the new infrastructures and criticized or commented on them or felt the need to express their own ideas. Figure 4 groups the options "none of them + other" and shows an increase in overall acceptance of the infrastructures built from $57.8 \%$ to $73.7 \%$. That is, not only did a majority of the population take a positive view of at least one of the new facilities, a few months later this percentage increased by nearly 16 percentage points. Of the new infrastructures, the two with the majority were parking space and creation of shared bicycle lanes.

Question 6 asked citizens if they thought that new bike facilities projects helped promote travel by bicycle. The opinion of a total of $76.5 \%$ of those surveyed was "yes" or "maybe" in November-December 2019, while in February-March 2020, the percentage of these two choices rose to $79.6 \%$ (Table 8). By age, a significant decrease was observed in those who answered "no" between the first and second survey among the youngest (10 points), moderate in the 30-49 age group (6 points), an increase in the 50-64 age group (11 points), and a decrease among those over 65 (22 points) (Table 9).

Question 7 offered the possibility of choosing up to three possible answers from a total of seven choices. If positive choices are grouped together (investment in new facilities is recommended, important, necessary, positive, innovator) and compared to negative (absurd, excessive, unnecessary, premature), in both rounds, the first group was clearly in the majority. Furthermore, in the second survey, it was found that the total of favorable opinions grew $9.9 \%$. Both genders had plainly positive opinions both times, and their interest also grew over time (Table 10). By age, in general terms, however, a favorable opinion was observed to grow among those under 50 years and fell in those over 50 (Table 11). 


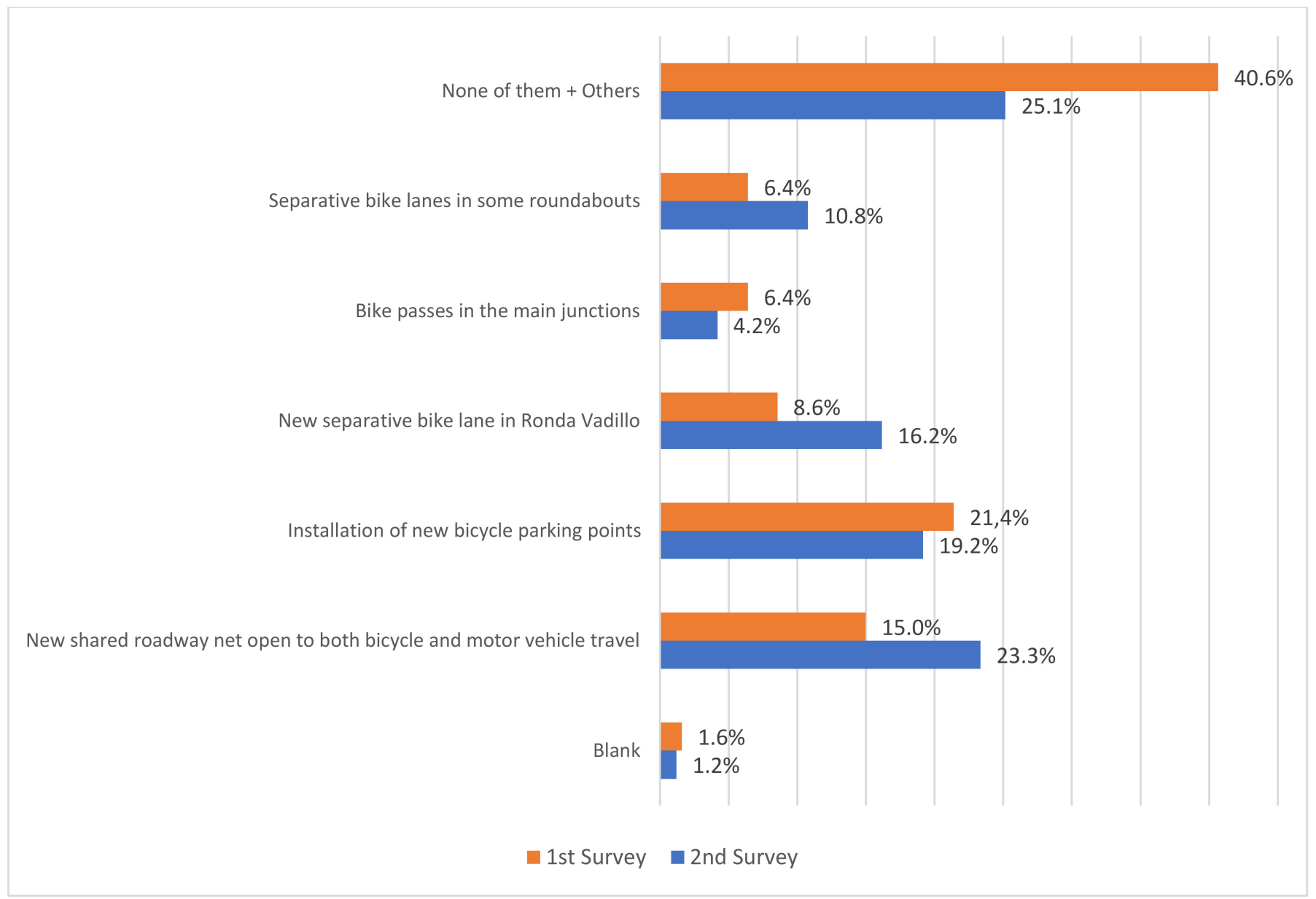

Figure 4. Question 5 responses, grouping the options "none of them + other".

Table 8. Question 6. Do you think that new bicycle facilities projects promote travel by bicycle? (by gender).

\begin{tabular}{|c|c|c|c|c|c|c|c|c|c|c|c|c|c|}
\hline \multirow[b]{3}{*}{ Yes } & \multicolumn{6}{|c|}{ 1st Survey } & \multicolumn{6}{|c|}{ 2nd Survey } & \multirow{3}{*}{$\begin{array}{c}\text { Difference } \\
2.6 \%\end{array}$} \\
\hline & \multicolumn{2}{|c|}{ Women } & \multicolumn{2}{|c|}{ Men } & \multicolumn{2}{|c|}{ Total } & \multicolumn{2}{|c|}{ Women } & \multicolumn{2}{|c|}{ Men } & \multicolumn{2}{|c|}{ Total } & \\
\hline & 70 & $42.7 \%$ & 122 & $58.0 \%$ & 192 & $51.4 \%$ & 32 & $45.7 \%$ & 58 & $59.8 \%$ & 90 & $53.9 \%$ & \\
\hline No & 44 & $26.8 \%$ & 44 & $21.0 \%$ & 88 & $23.5 \%$ & 14 & $20.0 \%$ & 19 & $19.6 \%$ & 33 & $19.8 \%$ & $-3.8 \%$ \\
\hline Maybe & 50 & $30.5 \%$ & 44 & $21.0 \%$ & 94 & $25.1 \%$ & 24 & $34.3 \%$ & 19 & $19.6 \%$ & 43 & $25.7 \%$ & $0.6 \%$ \\
\hline Blank & 0 & $0.0 \%$ & 0 & $0.0 \%$ & 0 & $0.0 \%$ & 0 & $0.0 \%$ & 1 & $1.0 \%$ & 1 & $0.6 \%$ & $0.6 \%$ \\
\hline
\end{tabular}

Source: the authors.

Table 9. Question 6. Do you think that new bicycle facilities projects promote travel by bicycle? (by age).

\begin{tabular}{|c|c|c|c|c|c|c|c|c|c|c|c|c|c|c|c|c|}
\hline \multirow[b]{3}{*}{ Yes } & \multicolumn{8}{|c|}{ 1st Survey } & \multicolumn{8}{|c|}{ 2nd Survey } \\
\hline & \multicolumn{2}{|c|}{$16-29$} & \multicolumn{2}{|c|}{$30-49$} & \multicolumn{2}{|c|}{$50-64$} & \multicolumn{2}{|c|}{$>65$} & \multicolumn{2}{|c|}{$16-29$} & \multicolumn{2}{|c|}{$30-49$} & \multicolumn{2}{|c|}{$50-64$} & \multicolumn{2}{|c|}{$>65$} \\
\hline & 33 & $41.2 \%$ & 94 & $48.7 \%$ & 48 & $64.9 \%$ & 3 & $50.0 \%$ & 17 & $56.7 \%$ & 46 & $51.1 \%$ & 21 & $55.3 \%$ & 6 & $66.7 \%$ \\
\hline No & 19 & $23.8 \%$ & 53 & $27.5 \%$ & 9 & $12.1 \%$ & 2 & $33.3 \%$ & 4 & $13.3 \%$ & 19 & $21.1 \%$ & 9 & $23.7 \%$ & 1 & $11.1 \%$ \\
\hline Maybe & 28 & $35.0 \%$ & 46 & $23.8 \%$ & 17 & $23.0 \%$ & 1 & $16.7 \%$ & 9 & $30.0 \%$ & 25 & $27.8 \%$ & 7 & $18.4 \%$ & 2 & $22.2 \%$ \\
\hline Blank & 0 & $0.0 \%$ & 0 & $0.0 \%$ & 0 & $0.0 \%$ & 0 & $0.0 \%$ & 0 & $0.0 \%$ & 0 & $0.0 \%$ & 1 & $2.6 \%$ & 0 & $0.0 \%$ \\
\hline
\end{tabular}

Source: the authors. 
Table 10. Question 7. Do you think that investing in bicycle infrastructure in Cáceres is: (you can answer with up to three choices) (by gender).

\begin{tabular}{|c|c|c|c|c|c|c|c|c|c|c|c|c|c|}
\hline \multirow[b]{3}{*}{ Recommended } & \multicolumn{6}{|c|}{ 1st Survey } & \multicolumn{6}{|c|}{ 2nd Survey } & \multirow{3}{*}{$\begin{array}{c}\text { Difference } \\
4.7 \%\end{array}$} \\
\hline & \multicolumn{2}{|c|}{ Women } & \multicolumn{2}{|c|}{ Men } & \multicolumn{2}{|c|}{ Total } & \multicolumn{2}{|c|}{ Women } & \multicolumn{2}{|c|}{ Men } & \multicolumn{2}{|c|}{ Total } & \\
\hline & 49 & $14.1 \%$ & 100 & $18.9 \%$ & 149 & $17.0 \%$ & 34 & $22.2 \%$ & 51 & $21.3 \%$ & 85 & $21.7 \%$ & \\
\hline Important & 47 & $13.5 \%$ & 84 & $15.9 \%$ & 131 & $14.9 \%$ & 24 & $15.7 \%$ & 39 & $16.3 \%$ & 63 & $16.1 \%$ & $1.2 \%$ \\
\hline Necessary & 49 & $14.1 \%$ & 87 & $16.4 \%$ & 136 & $15.5 \%$ & 20 & $13.1 \%$ & 43 & $18.0 \%$ & 63 & $16.1 \%$ & $0.6 \%$ \\
\hline Positive & 55 & $15.8 \%$ & 99 & $18.7 \%$ & 154 & $17.6 \%$ & 35 & $22.8 \%$ & 51 & $21.3 \%$ & 86 & $21.9 \%$ & $4.3 \%$ \\
\hline Innovator & 23 & $6.6 \%$ & 25 & $4.8 \%$ & 48 & $5.5 \%$ & 9 & $5.9 \%$ & 9 & $3.8 \%$ & 18 & $4.6 \%$ & $-0.9 \%$ \\
\hline Total positives & 223 & $64.1 \%$ & 395 & $74.7 \%$ & 618 & $70.5 \%$ & 122 & $79.7 \%$ & 193 & $80.7 \%$ & 315 & $80.4 \%$ & $9.9 \%$ \\
\hline Absurd & 37 & $10.7 \%$ & 40 & $7.6 \%$ & 77 & $8.8 \%$ & 11 & $7.2 \%$ & 13 & $5.4 \%$ & 24 & $6.1 \%$ & $-2.7 \%$ \\
\hline Excessive & 29 & $8.3 \%$ & 21 & $4.0 \%$ & 50 & $5.7 \%$ & 6 & $3.9 \%$ & 8 & $3.4 \%$ & 14 & $3.5 \%$ & $-2.2 \%$ \\
\hline Unnecessary & 30 & $8.6 \%$ & 39 & $7.4 \%$ & 69 & $7.8 \%$ & 11 & $7.2 \%$ & 14 & $5.9 \%$ & 25 & $6.4 \%$ & $-1.4 \%$ \\
\hline Premature & 29 & $8.3 \%$ & 34 & $6.4 \%$ & 63 & $7.2 \%$ & 3 & $2.0 \%$ & 11 & $4.6 \%$ & 14 & $3.6 \%$ & $-3.6 \%$ \\
\hline Total negatives & 125 & $35.9 \%$ & 134 & $25.3 \%$ & 259 & $29.5 \%$ & 31 & $20.3 \%$ & 46 & $19.3 \%$ & 77 & $19.6 \%$ & $-9.9 \%$ \\
\hline
\end{tabular}

Source: the authors.

Table 11. Question 7. Do you think that investing in bicycle infrastructure in Cáceres is: (you can answer with up to three choices) (by age).

\begin{tabular}{|c|c|c|c|c|c|c|c|c|c|c|c|c|c|c|c|c|}
\hline \multirow[b]{3}{*}{ Recommended } & \multicolumn{8}{|c|}{ 1st Survey } & \multicolumn{8}{|c|}{ 2nd Survey } \\
\hline & \multicolumn{2}{|c|}{$16-29$} & \multicolumn{2}{|c|}{$30-49$} & \multicolumn{2}{|c|}{$50-64$} & \multicolumn{2}{|c|}{$>65$} & \multicolumn{2}{|c|}{$16-29$} & \multicolumn{2}{|c|}{$30-49$} & \multicolumn{2}{|c|}{$50-64$} & \multicolumn{2}{|c|}{$>65$} \\
\hline & 25 & $12.4 \%$ & 72 & $16.0 \%$ & 39 & $23.1 \%$ & 2 & $16.7 \%$ & 13 & $18.6 \%$ & 43 & $19.3 \%$ & 23 & $33.8 \%$ & 6 & $24.0 \%$ \\
\hline Important & 27 & $13.4 \%$ & 67 & $14.9 \%$ & 31 & $18.4 \%$ & 1 & $8.3 \%$ & 14 & $20.0 \%$ & 39 & $17.5 \%$ & 7 & $10.3 \%$ & 3 & $12.0 \%$ \\
\hline Necessary & 27 & $13.4 \%$ & 74 & $16.4 \%$ & 28 & $16.6 \%$ & 2 & $16.7 \%$ & 17 & $24.3 \%$ & 37 & $16.6 \%$ & 2 & $2.9 \%$ & 2 & $8.0 \%$ \\
\hline Positive & 35 & $17.4 \%$ & 79 & $17.6 \%$ & 27 & $16.0 \%$ & 4 & $33.3 \%$ & 18 & $25.8 \%$ & 49 & $22.0 \%$ & 12 & $17.7 \%$ & 7 & $28.0 \%$ \\
\hline Innovator & 20 & $10.0 \%$ & 17 & $3.8 \%$ & 8 & $4.7 \%$ & 1 & $8.4 \%$ & 2 & $2.9 \%$ & 11 & $4.9 \%$ & 4 & $5.9 \%$ & 1 & $4.0 \%$ \\
\hline Total positives & 134 & $66.6 \%$ & 309 & $68.7 \%$ & 133 & $78.8 \%$ & 10 & $83.4 \%$ & 64 & $91.4 \%$ & 179 & $80.3 \%$ & 48 & $70.6 \%$ & 19 & $76.0 \%$ \\
\hline Absurd & 24 & $11.9 \%$ & 35 & $7.8 \%$ & 11 & $6.5 \%$ & 1 & $8.3 \%$ & 2 & $2.9 \%$ & 14 & $6.3 \%$ & 7 & $10.3 \%$ & 1 & $4.0 \%$ \\
\hline Excessive & 9 & $4.5 \%$ & 32 & $7.1 \%$ & 8 & $4.7 \%$ & 0 & $0.0 \%$ & 1 & $1.4 \%$ & 9 & $4.0 \%$ & 3 & $4.4 \%$ & 1 & $4.0 \%$ \\
\hline Unnecessary & 15 & $7.5 \%$ & 39 & $8.6 \%$ & 10 & $5.9 \%$ & 1 & $8.3 \%$ & 1 & $1.4 \%$ & 14 & $6.3 \%$ & 7 & $10.3 \%$ & 2 & $8.0 \%$ \\
\hline Premature & 19 & $9.5 \%$ & 35 & $7.8 \%$ & 7 & $4.1 \%$ & 0 & $0.0 \%$ & 2 & $2.9 \%$ & 7 & $3.1 \%$ & 3 & $4.4 \%$ & 2 & $8.0 \%$ \\
\hline Total negatives & 67 & $33.4 \%$ & 141 & $31.3 \%$ & 36 & $21.2 \%$ & 2 & $16.6 \%$ & 6 & $8.6 \%$ & 44 & $19.7 \%$ & 20 & $29.4 \%$ & 6 & $24.0 \%$ \\
\hline
\end{tabular}

Source: the authors.

Figures 5 and 6 show the evolution of the answers. In general, it was found that positive attributes were maintained or increased, and some relatively homogeneous figures were maintained. Finally, the percentage of persons surveyed who considered the construction of a bike lane innovative is not very high and diminishes in both men and women over time. This is surprising because in Cáceres there were hardly any bike lines, and only on the outskirts. Those surveyed therefore think the city lacked an infrastructure, which in 2020 was already hardly innovative and at the same time was important, necessary or advisable. By age, those under 50 were grouped together on one side and those over 49 on the other. Clear uniformity was observed in the growth of the "recommended" label in all the sections, and in the decrease in values referring to "innovative" and "premature". In the rest of the positive labels, a clear generational divergence was found, especially in "necessary".

The next question, no.8, referred to further steps to be taken by government administration. In this case, the questionnaire made it possible to answer simultaneously to several choices and also provided the possibility of adding suggestions. In this case, the variety of answers was grouped together in a single line to compare them with the option "There is enough with what there is." This choice was picked by $15.2 \%$ of those surveyed the first time, and by $12.0 \%$ the second. This leaves a 3.2\% decrease between the two. The overall set of answers to the choice "There is enough" decreased in both genders, although 
the percentage of women who thought no more action needed to be taken was almost double that of men (Table 12). The data by age show that "it is enough" dropped in the 16-29 group, went down slightly in the 30-49, went up slightly from 50-64, and increased sharply among those over 65 . There is, therefore, an inverse relationship between age and what could be called "conformism" with what was constructed (Table 13).

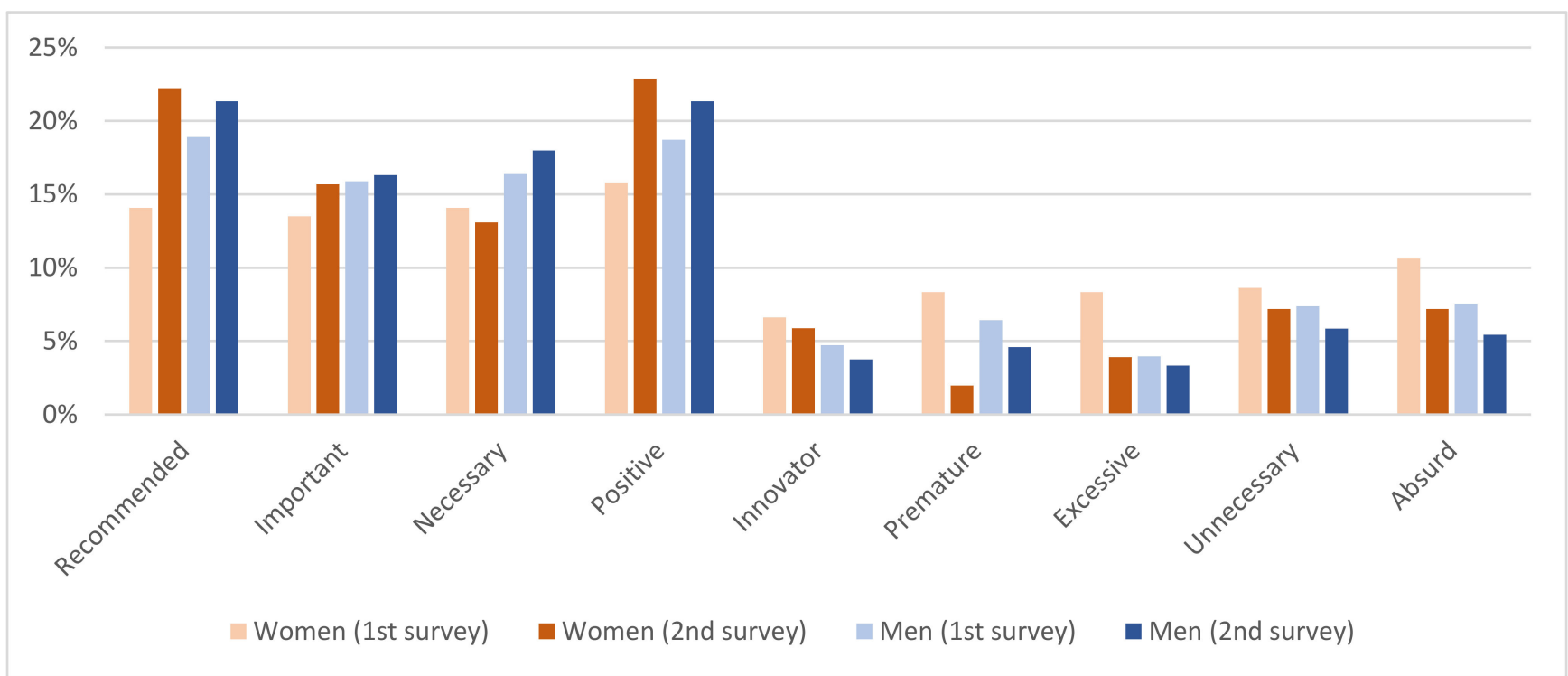

Figure 5. Evolution of answers in Question 7 (by gender).

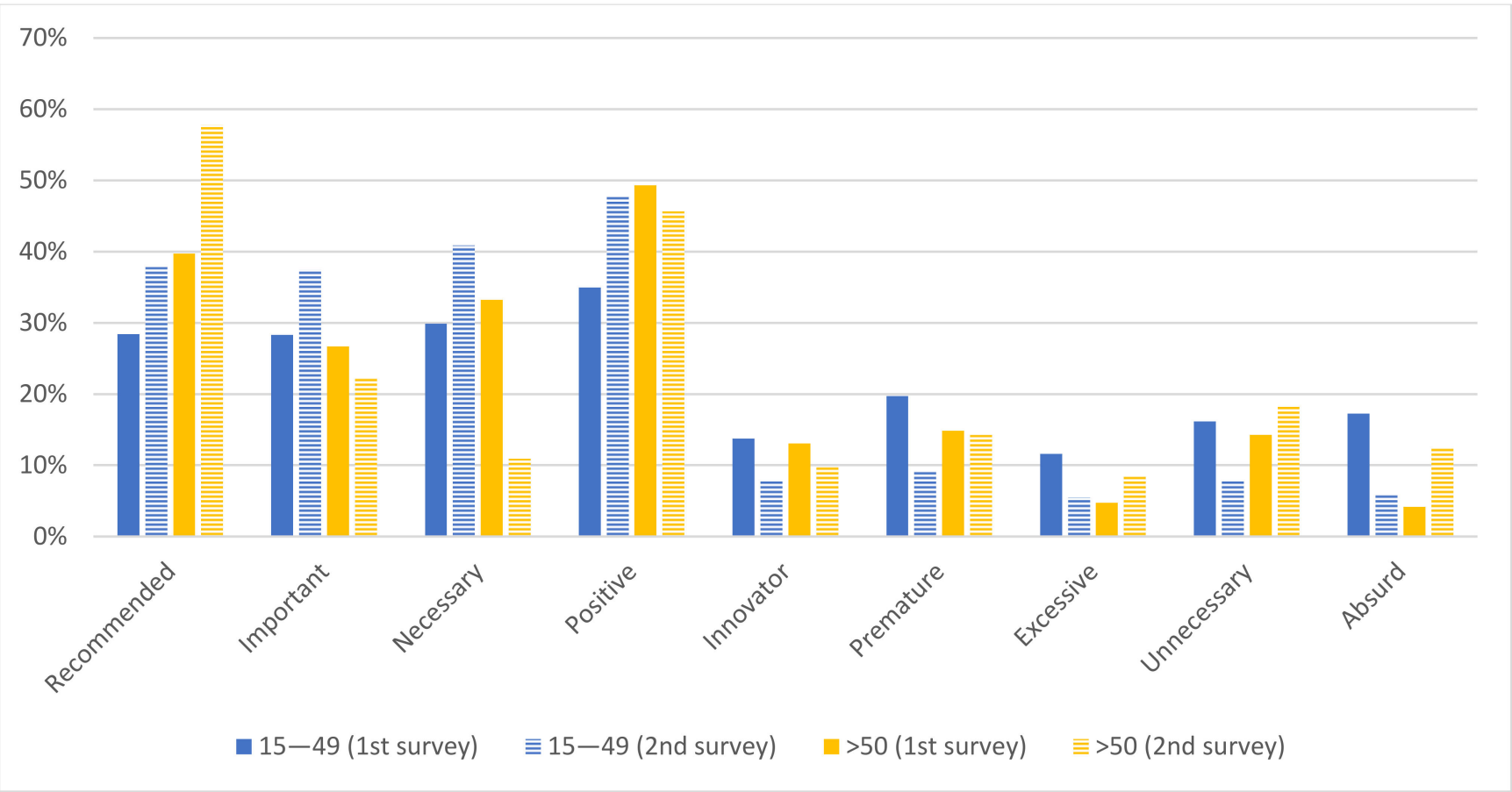

Figure 6. Evolution of answers in Question 7 (by age). 
Table 12. Question 8. In Cáceres, in your opinion, what further steps should be taken by government administration, concerning bike or VMP mobility? (you can answer with several choices) (by gender).

\begin{tabular}{|c|c|c|c|c|c|c|c|c|c|c|c|c|c|}
\hline \multirow[b]{3}{*}{ It is enough } & \multicolumn{6}{|c|}{ 1st Survey } & \multicolumn{6}{|c|}{ 2nd Survey } & \multirow{3}{*}{$\begin{array}{c}\text { Difference } \\
-3.2 \%\end{array}$} \\
\hline & \multicolumn{2}{|c|}{ Women } & \multicolumn{2}{|c|}{ Men } & \multicolumn{2}{|c|}{ Total } & \multicolumn{2}{|c|}{ Women } & \multicolumn{2}{|c|}{ Men } & \multicolumn{2}{|c|}{ Total } & \\
\hline & 35 & $21.3 \%$ & 22 & $10.5 \%$ & 57 & $15.2 \%$ & 12 & $17.2 \%$ & 8 & $8.3 \%$ & 20 & $12.0 \%$ & \\
\hline $\begin{array}{l}\text { Sum of responses } \\
\text { but blank answers } \\
\text { or "it is enough" }\end{array}$ & 118 & $72.0 \%$ & 179 & $85.2 \%$ & 297 & $79.4 \%$ & 54 & $77.1 \%$ & 85 & $87.6 \%$ & 139 & $83.2 \%$ & $3.8 \%$ \\
\hline Blank & 11 & $6.7 \%$ & 9 & $4.3 \%$ & 20 & $5.4 \%$ & 4 & $5.7 \%$ & 4 & $4.1 \%$ & 8 & $4.8 \%$ & $-0.6 \%$ \\
\hline
\end{tabular}

Table 13. Question 8. In Cáceres, in your opinion, what further steps should be taken by government administration, concerning bike or VMP mobility? (you can answer with several choices) (by age).

\begin{tabular}{|c|c|c|c|c|c|c|c|c|c|c|c|c|c|c|c|c|}
\hline \multirow{5}{*}{$\begin{array}{l}\text { It is enough } \\
\text { Sum of responses } \\
\text { but blank answers } \\
\text { or "it is enough" }\end{array}$} & \multicolumn{8}{|c|}{ 1st Survey } & \multicolumn{8}{|c|}{ 2nd Survey } \\
\hline & \multicolumn{2}{|c|}{$16-29$} & \multicolumn{2}{|c|}{$30-49$} & \multicolumn{2}{|c|}{$50-64$} & \multicolumn{2}{|c|}{$>65$} & \multicolumn{2}{|c|}{$16-29$} & \multicolumn{2}{|c|}{$30-49$} & \multicolumn{2}{|c|}{$50-64$} & \multicolumn{2}{|c|}{$>65$} \\
\hline & 14 & $17.5 \%$ & 34 & $17.6 \%$ & 7 & $9.5 \%$ & 1 & $16.7 \%$ & 1 & $3.3 \%$ & 12 & $13.3 \%$ & 5 & $13.2 \%$ & 2 & $22.2 \%$ \\
\hline & 64 & $80.0 \%$ & 149 & $77.2 \%$ & 63 & $85.1 \%$ & 3 & $50.0 \%$ & 29 & $96.7 \%$ & 74 & $82.2 \%$ & 29 & $76.3 \%$ & 7 & $77.8 \%$ \\
\hline & 2 & $2.5 \%$ & 10 & $5.2 \%$ & 4 & $5.4 \%$ & 2 & $33.3 \%$ & 0 & $0.0 \%$ & 4 & $4.5 \%$ & 4 & $10.5 \%$ & 0 & $0.0 \%$ \\
\hline
\end{tabular}

Question 9 asked whether bicycle traffic safety had increased. It may be observed that the percentage that chose "a lot, it has changed noticeably" was very low: $2.6 \%$ in the first round and $2.4 \%$ the second time. However, there are two intermediate groups (those who indicated that it was "quite a lot, the difference is noticeable" and "a little, although there is still much to be done"), which increased over the months, (by 7.5\% and $8.1 \%$ respectively). Furthermore, the percentage of those who marked "not at all" diminished by $15.0 \%$. By gender, there were notable differences in the answers to this choice: $44.3 \%$ of men chose it in November-December 2019, and however, in February-March 2020, it went down to $23.7 \%$. For women, it was $39.0 \%$ in November-December and fell to $31.4 \%$. Men were therefore observed to be more unwilling to admit some type of improvement in bike traffic safety in the beginning, but 3 months later were more enthusiastic (Table 14). By age, there was a clearly uniform response in all the groups with regard to growth of "quite a lot", "the difference is noticeable" and decrease in "nothing" (Table 15).

Table 14. Question 9. In your opinion, has the new bicycle infrastructure increased traffic safety for bikes in Cáceres? (by gender).

\begin{tabular}{|c|c|c|c|c|c|c|c|c|c|c|c|c|c|}
\hline \multirow{2}{*}{ Quite a lot, the } & \multicolumn{6}{|c|}{ 1st Survey } & \multicolumn{6}{|c|}{ 2nd Survey } & \multirow{2}{*}{ Difference } \\
\hline & \multicolumn{2}{|c|}{ Women } & \multicolumn{2}{|c|}{ Men } & \multicolumn{2}{|c|}{ Total } & \multicolumn{2}{|c|}{ Women } & \multicolumn{2}{|c|}{ Men } & \multicolumn{2}{|c|}{ Total } & \\
\hline $\begin{array}{c}\text { difference is } \\
\text { noticeable }\end{array}$ & 11 & $6.7 \%$ & 17 & $8.1 \%$ & 28 & $7.5 \%$ & 9 & $12.9 \%$ & 16 & $16.5 \%$ & 25 & $15.0 \%$ & $7.5 \%$ \\
\hline $\begin{array}{c}\text { A lot, it has } \\
\text { changed noticeably }\end{array}$ & 7 & $4.3 \%$ & 3 & $1.4 \%$ & 10 & $2.6 \%$ & 1 & $1.4 \%$ & 3 & $3.1 \%$ & 4 & $2.4 \%$ & $-0.2 \%$ \\
\hline Nothing & 64 & $39.0 \%$ & 93 & $44.3 \%$ & 157 & $42.0 \%$ & 22 & $31.4 \%$ & 23 & $23.7 \%$ & 45 & $26.9 \%$ & $-15.1 \%$ \\
\hline $\begin{array}{l}\text { A Little, although } \\
\text { much remains to } \\
\text { be done }\end{array}$ & 82 & $50.0 \%$ & 96 & $45.7 \%$ & 178 & $47.6 \%$ & 38 & $54.3 \%$ & 55 & $56.7 \%$ & 93 & $55.7 \%$ & $8.1 \%$ \\
\hline Blank & 0 & $0.0 \%$ & 1 & $0.5 \%$ & 1 & $0.3 \%$ & 0 & $0.0 \%$ & 0 & $0.0 \%$ & 0 & $0.0 \%$ & $-0.3 \%$ \\
\hline
\end{tabular}


Table 15. Question 9. In your opinion, has the new bicycle infrastructure increased traffic safety for bikes in Cáceres? (by age).

\begin{tabular}{|c|c|c|c|c|c|c|c|c|c|c|c|c|c|c|c|c|}
\hline & \multicolumn{8}{|c|}{ 1st Survey } & \multicolumn{8}{|c|}{ 2nd Survey } \\
\hline & \multicolumn{2}{|c|}{$16-29$} & \multicolumn{2}{|c|}{$30-49$} & \multicolumn{2}{|c|}{$50-64$} & \multicolumn{2}{|c|}{$>65$} & \multicolumn{2}{|c|}{$16-29$} & \multicolumn{2}{|c|}{$30-49$} & \multicolumn{2}{|c|}{$50-64$} & \multicolumn{2}{|c|}{$>65$} \\
\hline $\begin{array}{c}\text { difference is } \\
\text { noticeable }\end{array}$ & 4 & $5.0 \%$ & 11 & $5.7 \%$ & 8 & $10.8 \%$ & 1 & $16.7 \%$ & 5 & $16.7 \%$ & 11 & $12.2 \%$ & 8 & $21.0 \%$ & 1 & $11.1 \%$ \\
\hline $\begin{array}{c}\text { A lot, it has } \\
\text { changed noticeably }\end{array}$ & 2 & $2.5 \%$ & 5 & $2.6 \%$ & 3 & $4.1 \%$ & 0 & $0.0 \%$ & 1 & $3.3 \%$ & 3 & $3.3 \%$ & 0 & $0.0 \%$ & 0 & $0.0 \%$ \\
\hline Nothing & 28 & $35.0 \%$ & 87 & $45.1 \%$ & 31 & $41.9 \%$ & 2 & $33.3 \%$ & 8 & $26.7 \%$ & 26 & $28.9 \%$ & 10 & $26.3 \%$ & 1 & $11.1 \%$ \\
\hline $\begin{array}{l}\text { A Little, although } \\
\text { much remains to } \\
\text { be done }\end{array}$ & 45 & $56.2 \%$ & 90 & $46.6 \%$ & 32 & $43.2 \%$ & 3 & $50.0 \%$ & 16 & $53.3 \%$ & 50 & $55.6 \%$ & 20 & $52.7 \%$ & 7 & $77.8 \%$ \\
\hline Blank & 1 & $1.3 \%$ & 0 & $0.0 \%$ & 0 & $0.0 \%$ & 0 & $0.0 \%$ & 0 & $0.0 \%$ & 0 & $0.0 \%$ & 0 & $0.0 \%$ & 0 & $0.0 \%$ \\
\hline
\end{tabular}

\section{Discussion}

The two surveys enabled two types of conclusions to be arrived at: those derived only from analysis of the first survey, and those derived from studying both.

In the first survey, incidence of the bike lane was positive, as $12.8 \%$ of the population had used the bicycle for some new reason. This figure approached those who thought traffic safety had improved much or rather a lot: $10.1 \%$. Therefore, there seems to be a direct relationship between appreciation of an improvement in safety and use of the bicycle. In addition, one group of the population rejected installation of the bicycle infrastructure: $40.6 \%$ did not see anything good about any of the facilities built, $23.5 \%$ thought that the introduction of new projects would not cause any increase in use of bicycles, and $15.2 \%$ thought there was enough with what there is. That is, one group of the population (at least $15.2 \%$ ) did not even accept that the use of bicycles could be induced by building cyclist infrastructures. Of these, $15.2-23.5 \%$ and $40.6 \%$ of those who did not see any good in any of the facilities, a second group, was more tolerant of the bicycle as a means of urban transport but distrusted the new intervention.

A second group of conclusions emerges from the analysis of both surveys. In the first place, the answers received show that all the indicators chosen developed favorably toward acceptance of the new infrastructure. If October is taken as the first month when the infrastructure was already in use, its perceived acceptance during months 2-3 was demonstrably increased in months 5-6. From this, it may be inferred that the cyclist infrastructures built in Cáceres required a period of acceptance by the citizenship. Thus, the results described in this paper illustrate that there is a period of acceptance.

Five months after the new network was put into use, $17.4 \%$ of the population had ridden their bicycle for some new reason. Again, there is a correlation between this figure and those who consider traffic safety much or rather improved: also $17.4 \%$. Therefore, the study confirmed that there is a direct relationship between appreciation that safety has improved and riding a bicycle. The population that rejected installation of the cyclist infrastructure can also be assessed in somewhat more detail: $25.1 \%$ did not see anything good in the new facilities built, $19.8 \%$ thought that introduction of new projects would not lead to an increase in travel by bicycle, $12.0 \%$ considered that there is enough with what there is. That is, the most unwilling part of the population was still above $10 \%$ and this second group, which we defined as "tolerant of the bicycle as a means of urban transportation", and which however, "was distrustful of the intervention", decreased considerably.

These figures can be compared with the effect of new bicycles schemes in different medium-size European cities. Freiburg (Germany) increased the bicycle share of trips from $15 \%$ in 1982 to $27 \%$ in 2007 [42]; Muenster (Germany) from 23\% in 1994 to 25\% in 2002 [42]. 
In Seville, a bigger city but also a Spanish one, bicycle trips increased from 5\% in 2007 to $9 \%$ in 2011 [43], and in Barcelona, a big metropolis but with a lack of bicycle culture until recent years, new infrastructures increased the bicycle share of trips from $0.75 \%$ in 2005 to $1.76 \%$ in 2007 [44].

Moreover, the study confirmed a gender effect, shown to be an important indicator of the patterns of use of nonmotor vehicles as a means of transportation [45]. In general, the stronger enthusiasm of men for use of bicycles has been observed in studies done in other cities [46]. This reality has also been highlighted in small cities where the climate is warm [47], as precisely in the case of Cáceres, or cities without a relevant cycling infrastructure network [48]. Analyzing the data in the first survey, more use was made of new infrastructure in men's habits (a higher percentage of men who rode a bicycle for some new reason 2 months after the infrastructure went into use: 16.2\% compared to 8.5\%), even though women were slightly more optimistic insofar as perception of improved safety for bicycle riding ( $11.0 \%$ women compared to $9.5 \%$ men). In general, men also rejected the new project and construction of new improvements less. Taking the data from both surveys, it was again found that use of the new infrastructure was stronger by men, who were also more enthusiastic about safety of riding a bicycle. Neither do they reject the new project or construction of new improvements in general.

The study demonstrated the difference in the opinions the age groups had of the bicycle as a means of transportation, an effect usually observed in other studies [48-50]. The data from the first survey showed stronger public interest in older people in the new means of transportation, a more intense expectation that the bicycle infrastructures would promote an increase in use by cyclists, a more positive opinion of investing in new infrastructures and a stronger feeling that the new infrastructures increase safety of bicycle transportation. It was also observed that in all the questions, the positive opinion of the new infrastructure increased with age. If the data from both surveys are analyzed though, there is no direct relationship between age groups and the evolution of the answers to the set of questions. In general, there is strong enthusiasm by the youngest participants (16-29 years old) and a moderate growth in the rest of the age groups. A directly inverse relationship was found between age and what could be defined as "conformism" with what has already been constructed. We should also recall that there were very few participants aged $>65$, and therefore the analysis of its evolution is not very representative.

In terms of representativeness, the results presented were obtained from a study carried out in the city of Cáceres. The results therefore represent a look at the user in this specific system. Cáceres, however, can be considered an example of a small-size Mediterranean city $(97,000$ inhabitants) with a narrow range of mobility options, in a country with little cycling tradition. The findings on bicycle facility acceptance period found in this study are expected to be similar in other small-sized cities in countries with a similar cycling tradition. It would be interesting to gain more experience from other urban contexts in order to better understand the interaction between the different factors that shape bicycle acceptance. It would also be of interest to do a comparative study between this city and another located in a country with strong cyclist convictions, although it would be hard to find a middle-sized city without cyclist infrastructures already built in a country like the Netherlands or Denmark, where the first bicycling network had to be built from scratch.

\section{Conclusions}

This study analyzed the early impact of the construction of a new urban cycling infrastructure in Cáceres, a mid-size city with no previous cycling culture, located in Spain, a country with very little cycling tradition. The study was also intended to find out whether there were any changes in citizen attitude toward the cyclist infrastructure during the first months after it was put into use.

To do this, two online surveys were carried out: The first 2 months after infrastructure inauguration and the second 3 months after the first. The questions were on personal use 
of the new infrastructure created, their opinion of the new infrastructures, future steps that should be taken to continue promoting the bicycle, and eventual improvement of safety for cyclists provided by the new actions, among others.

There are some limitations to this study related to the sample size and its representativeness. The population over 15 years of age in Cáceres is 82,615. For a 95\% confidence level, the margin of error in the first survey is $5.06 \%$, and in the second round $7.58 \%$ (considering a normal distribution). It would have been ideal to have a larger number of participants, especially in the second round. Furthermore, as shown in Table 3, it was found that both women and people over 65 were clearly underrepresented. There were very few participants in this age group (six people in the first survey and nine in the second), so the study of the evolution of this segment of the population is not very reliable. This difference in age may be related to the survey's channels for diffusion and data reception. Therefore, and this is another conclusion of the study, we think the online survey method should be complemented with some other method that ensures better penetration of the survey among the older population (at least in studies in cities where there is a considerable digital divide).

Moreover, this study showed that public policies directed at construction of a new cyclist infrastructure are necessary to generate a change in citizenship attitude toward this new mode of transportation. Other studies $[44,51]$ have shown that to achieve a significant increase in the use of the bicycle, an integrated package of interventions, from the construction of the cyclist infrastructure to education and promotional programs, must also be implemented. It would therefore be of interest for Cáceres to implement an education program in the short term and for its incidence to be analyzed in a study parallel to its implementation. In terms of public investment, the cost of the infrastructure created, $143,000 €$ for 96,720 inhabitants, equivalent to $1.48 €$ per inhabitant, according to this survey, has caused a relevant change in the city's transportation dynamics.

Finally, the study done leaves the way open to more detailed studies on the implementation of the cyclist infrastructure in Cáceres. It would be desirable to observe development in the next years, after the COVID-19 effect, to be able to analyze whether the data become consolidated over time. Another interesting field of study would be analysis of the evolution of accidents between bicycles and motor vehicles in a city where a cyclist network has been set up. Gradual awareness (and respect) of motorized drivers for bicycles could thus be found. Elsewhere, the possibility of developing an inferential statistics research with this same data remains open.

Funding: This research received no external funding.

Institutional Review Board Statement: Not applicable.

Informed Consent Statement: Informed consent statement was obtained form all subject involved in the study.

Data Availability Statement: The data presented in this study are available on request from the corresponding author. The data are not publicity available. The data were obtained on the basis of own research.

Acknowledgments: Part of the research was done during a research visit at the Sapienza Università di Roma in September 2020. The author wishes to express especially his gratitude to Maria Martone for her help during the visit. Furthermore, the author wishes to express his gratitude to the reviewers, whose comments and suggestions have enhanced the original text. Moreover, the author appreciates the collaboration for the availability of data from the construction project to DeViarios SL (Eng Hadrián Arias, Montserrat Carballeira) and municipal Eng Carlos Muro, coauthors of the project.

Conflicts of Interest: The author declare no conflict of interest. 


\section{References}

1. Frank, L.D.; Sallis, J.F.; Conway, T.L.; Chapman, J.E.; Saelens, B.E.; Bachman, W. Many Pathways from Land Use to Health: Associations between Neighborhood Walkability and Active Transportation, Body Mass Index, and Air Quality. J. Am. Plan. Assoc. 2006, 72, 75-87. [CrossRef]

2. Gotschi, T. Costs and Benefits of Bicycling Investments in Portland, Oregon. J. Phys. Act. Health 2011, 8, S49-S58. [CrossRef]

3. Mueller, N.; Rojas-Rueda, D.; Salmon, M.; Martinez, D.; Ambros, A.; Brand, C.; Nieuwenhuijsen, M. Health impact assessment of cycling network expansions in European cities. Prev. Med. 2018, 109, 62-70. [CrossRef]

4. European Union Special Euribarometer 406. Attitudes of Europeans Towads Urban Mobility 2013. Available online: https://ec. europa.eu/commfrontoffice/publicopinion/archives/ebs/ebs_406_en.pdf (accessed on 20 June 2020).

5. European Union Special Eurobarometer 422a. Quality of Transport 2014. Available online: https://ec.europa.eu/ commfrontoffice/publicopinion/archives/ebs/ebs_422a_en.pdf (accessed on 20 June 2020).

6. Observatorio de la Movilidad Metropolitana 2004-2019. Available online: http:/ /www.observatoriomovilidad.es/es/publicaciones/ informes.html (accessed on 20 June 2020).

7. Morales Carballo, L. La movilidad ciclista como factor de sostenibilidad: Breve análisis de su emergencia en la ciudad de Sevilla. Hábitat Y Soc. 2011, 2, 109-130. [CrossRef]

8. Nelson, A.C.; Allen, D. If You Build Them, Commuters Will Use Them: Association Between Bicycle Facilities and Bicycle Commuting. Transp. Res. Rec. J. Transp. Res. Board 1997, 1578, 79-83. [CrossRef]

9. Dill, J.; Carr, T. Bicycle Commuting and Facilities in Major U.S. Cities: If You Build Them, Commuters Will Use Them. Transp. Res. Rec. J. Transp. Res. Board 2003, 1828, 116-123. [CrossRef]

10. Tilahun, N.Y.; Levinson, D.M.; Krizek, K.J. Trails, lanes, or traffic: Valuing bicycle facilities with an adaptive stated preference survey. Transp. Res. Part A Policy Pract. 2007, 41, 287-301. [CrossRef]

11. Nikitas, A. How to Save Bike-Sharing: An Evidence-Based Survival Toolkit for Policy-Makers and Mobility Providers. Sustainability 2019, 11, 3206. [CrossRef]

12. Hardinghaus, M.; Papantoniou, P. Evaluating Cyclists' Route Preferences with Respect to Infrastructure. Sustainability 2020, 12, 3375. [CrossRef]

13. Nikitas, A. Understanding bike-sharing acceptability and expected usage patterns in the context of a small city novel to the concept: A story of "Greek Drama". Transp. Res. Part F Traffic Psychol. Behav. 2018, 56, 306-321. [CrossRef]

14. Bovy, P.H.L.; Bradley, M.A. Route choice analyzed with stated preference approaches. Transp. Res. Rec. 1985, 1037, 11-20.

15. Hopkinson, P.; Wardman, M. Evaluating the demand for new cycle facilities. Transp. Policy 1996, 3, 241-249. [CrossRef]

16. Reynolds, C.C.; Harris, M.A.; Teschke, K.; Cripton, P.A.; Winters, M. The impact of transportation infrastructure on bicycling injuries and crashes: A review of the literature. Environ. Health 2009, 8, 47. [CrossRef] [PubMed]

17. Useche, S.; Montoro, L.; Alonso, F.; Oviedo-Trespalacios, O. Infrastructural and Human Factors Affecting Safety Outcomes of Cyclists. Sustainability 2018, 10, 299. [CrossRef]

18. Winters, M.; Davidson, G.; Kao, D.; Teschke, K. Motivators and deterrents of bicycling: Comparing influences on decisions to ride. Transportation 2011, 38, 153-168. [CrossRef]

19. Sanders, R.L. Perceived traffic risk for cyclists: The impact of near miss and collision experiences. Accid. Anal. Prev. 2015, 75, 26-34. [CrossRef] [PubMed]

20. Pérez López, R. Vínculos entre la bicicleta utilitaria, recreativa y deportiva: Análisis del impacto de los programas "Ecobici" y “Muévete en Bici" de la Ciudad de México (2006-2012). Transp. Y Territ. 2017, 16, 220-234.

21. Fuller, D.; Gauvin, L.; Kestens, Y.; Daniel, M.; Fournier, M.; Morency, P.; Drouin, L. Impact Evaluation of a Public Bicycle Share Program on Cycling: A Case Example of BIXI in Montreal, Quebec. Am. J. Public Health 2013, 103, e85-e92. [CrossRef]

22. Molina-Garcia, J.; Castillo, I.; Queralt, A.; Sallis, J.F. Bicycling to university: Evaluation of a bicycle-sharing program in Spain. Health Promot. Int. 2015, 30, 350-358. [CrossRef] [PubMed]

23. Ricci, M. Bike sharing: A review of evidence on impacts and processes of implementation and operation. Res. Transp. Bus. Manag. 2015, 15, 28-38. [CrossRef]

24. Mölenberg, F.J.M.; Panter, J.; Burdorf, A.; van Lenthe, F.J. A systematic review of the effect of infrastructural interventions to promote cycling: Strengthening causal inference from observational data. Int. J. Behav. Nutr. Phys. Act. 2019, 16, 93. [CrossRef]

25. Vasilev, M.; Pritchard, R.; Jonsson, T. Trialing a Road Lane to Bicycle Path Redesign—Changes in Travel Behavior with a Focus on Users' Route and Mode Choice. Sustainability 2018, 10, 4768. [CrossRef]

26. Goodman, A.; Sahlqvist, S.; Ogilvie, D. New walking and cycling routes and increased physical activity: One- and 2-year findings from the UK iConnect study. Am. J. Public Health 2014, 104, 38-46. [CrossRef]

27. Bike Infrastructures. Available online: https://vbn.aau.dk/en/publications/bike-infrastructures (accessed on 1 January 2010).

28. Blitz, A.; Busch-Geertsema, A.; Lanzendorf, M. More Cycling, Less Driving? Findings of a Cycle Street Intervention Study in the Rhine-Main Metropolitan Region, Germany. Sustainability 2020, 12, 805. [CrossRef]

29. Standen, C.; Crane, M.; Collins, A.; Greaves, S.; Rissel, C. Determinants of mode and route change following the opening of a new cycleway in Sydney, Australia. J. Transp. Health 2017, 4, 255-266. [CrossRef]

30. Sener, I.N.; Eluru, N.; Bhat, C.R. An analysis of bicycle route choice preferences in Texas, US. Transportation 2009, 36, 511-539. [CrossRef] 
31. Rissel, C.; Greaves, S.; Wen, L.M.; Capon, A.; Crane, M.; Standen, C. Evaluating the transport, health and economic impacts of new urban cycling infrastructure in Sydney, Australia-protocol paper. BMC Public Health 2013, 13, 963. [CrossRef] [PubMed]

32. Van Goeverden, K.; Nielsen, T.S.; Harder, H.; van Nes, R. Interventions in Bicycle Infrastructure, Lessons from Dutch and Danish Cases. Transp. Res. Procedia 2015, 10, 403-412. [CrossRef]

33. Plasencia-Lozano, P. La ciudad-racimo y la pérdida de la gran calle. In International Conference Virtual City and Territory; Università degli Studi Roma Tre: Roma, Italia, 2014.

34. Ayuntamiento de Cáceres. Estadísticas de Población; Ayuntamiento de Cáceres: Cáceres, Spain, 2019.

35. Cedar Lake Ventures Average weather in Cáceres. Available online: https://es.weatherspark.com/y/33408/Clima-promedio-enC\%C3\%A1ceres-Espa\%C3\%B1a-durante-todo-el-a\%C3\%B1o (accessed on 12 August 2020).

36. Ayuntamiento de Cáceres. Plan de Infraestructuras Para la Movilidad Urbana Sostenible; Ayuntamiento de Cáceres: Cáceres, Spain, 2014.

37. Bronner, F; Kuijlen, T. The Live or Digital Interviewer-A Comparison between CASI, CAPI and CATI with Respect to Differences in Response Behaviour. Int. J. Mark. Res. 2007, 49, 167-190. [CrossRef]

38. Heerwegh, D.; Loosveldt, G. Face-to-Face versus Web Surveying in a High-Internet-Coverage Population: Differences in Response Quality. Public Opin. Q. 2008, 72, 836-846. [CrossRef]

39. Bakogiannis, E.; Vassi, A.; Christodoulopoulou, G.; Siti, M. Bike Sharing Systems as a Tool to Increase Sustainable Coastal and Maritime Tourism: The Case of Piraeus. Reg. Sci. Inq. 2018, 10, 57-70.

40. García, J.; Arroyo, R.; Mars, L.; Ruiz, T. The Influence of Attitudes towards Cycling and Walking on Travel Intentions and Actual Behavior. Sustainability 2019, 11, 2554. [CrossRef]

41. Shao, Y.; Xu, X.; Jiang, L. Economic Valuation of the Renewal of Urban Streets: A Choice Experiment. Sustainability 2020, $12,4808$. [CrossRef]

42. Pucher, J.; Buehler, R. At the frontiers of cycling: Policy innovations in the Netherlands, Denmark, and Germany. World Transp. Policy Pract. 2007, 13, 8-57.

43. Marqués, R.; Hernández-Herrador, V.; Calvo-Salazar, M.; García-Cebrián, J.A. How infrastructure can promote cycling in cities: Lessons from Seville. Res. Transp. Econ. 2015, 53, 31-44. [CrossRef]

44. Pucher, J.; Dill, J.; Handy, S. Infrastructure, programs, and policies to increase bicycling: An international review. Prev. Med. 2010, 50, S106-S125. [CrossRef]

45. Law, R. Beyond "women and transport": Towards new geographies of gender and daily mobility. Prog. Hum. Geogr. 1999, 23, 567-588. [CrossRef]

46. Figueroa Martínez, C.; Waintrub Santibáñez, N. Movilidad femenina en Santiago de Chile: Reproducción de inequidades en la metrópolis, el barrio y el espacio público. Urbe. Rev. Bras. De Gestão Urbana 2015, 7, 48-61.

47. Williams, J.; Larson, J. Promoting bicycle commuting: Understanding the customer. Transp. Q. 1996, 50, 67-78.

48. Sabyrbekov, R.; Overland, I. Why Choose to Cycle in a Low-Income Country? Sustainability 2020, 12, 7775. [CrossRef]

49. Faboya, O.T.; Ryan, B.; Figueredo, G.P.; Siebers, P.O. Using agent-based modelling for investigating modal shift: The case of university travel. Comput. Ind. Eng. 2020, 139, 106077. [CrossRef]

50. Zheng, Y.; Ma, Y.; Cheng, J. Cycling anger in China: The relationship with gender roles, cycling-related experience, risky and aggressive riding. Transp. Res. Part F Traffic Psychol. Behav. 2020, 68, 52-66. [CrossRef]

51. Hernández Vega, H. Caracterización de la movilidad en bicicleta en el Campus Universitario Rodrigo Facio, Universidad de Costa Rica. Rev. Abra 2017, 37, 1. [CrossRef] 